\title{
Educational Transition and Adult Re-entry Programs
}

\author{
by Helen Khalouyan Pivk \\ Re-entry Counselor \\ West Valley College
}

Re-entry students are adults who are often motivated to return to school as a result of a major life change. This change could be the loss of a job, a divorce, death of a spouse, or career limitations due to lack of education. Some students are back to school to enhance their ability to become more educated and self-sufficient. Many adults returning to school are single parents. They usually are heads of households and are returning to school to prepare for a career that will financially support them and their family. These single parents mostly are women. They might be unemployed, working poor, single parents, new immigrants/refugees, or displaced homemakers. Some are recovering from substance abuse, are victims of domestic violence, or are leaving an abusive relationship. They may have lost a spouse, a child, a job, or just moved into the area and are fighting against many odds to be able to obtain an education.

\section{The Needs of Re-entry Students}

The needs of re-entry students in college are as complex as their reasons for returning to school after a short or long absence. They need specialized academic, career, and personal counseling. They need workshops and support groups. They need child care, transportation, and other services in the community to be able to return to college. They might also have relationship crises either with a spouse, child, or other life partner. Additionally, they may have various forms of disabilities, including learning disabilities, which present additional obstacles to classroom performance.

\section{The Benefits of Attending a Community College}

Community colleges often offer a warm atmosphere for adult re-entry students. Expenses at a community college are commonly much less than those at 4-year colleges, and they often offer more flexible course schedules to accommodate working professionals. These night and weekend classes, as well as those offered online or through television, can be important components in a decision to pursue an education. For returning students, these unique delivery methods are often the selling points for a given program. The undiscussed cost, though, is typically the loss of community or group support that can go with attendance in college.

There are over 40 public community colleges in Northern California. West Valley 
Community College is one of the seven community colleges in Santa Clara County. In addition to the educational programs offered, West Valley College provides an assortment of support services tailored to the needs of its student population. One of the most successful student services at West Valley College is the Educational Transition/Adult Reentry Program (ET).

\section{Educational Transition/Adult Re-entry Program}

ET started its operation at West Valley College in 1970 as a women's re-entry program, designed to assist women from the surrounding community in achieving higher education. During the last 30 years, ET has helped many students succeed in their programs of studies through specialized programs. These services are based on the many needs of adult students who are trying to change their lives.

The Educational Transition/Adult Re-entry Program serves mostly low-income and under-represented students, single parents, displaced homemakers, working poor, former welfare recipients, dislocated workers, and a large number of immigrants and refugees. Most programs within ET are provided through different grant opportunities. Due to the large number of women in the program, many of the grants provide services for single parents, displaced homemakers, and women majoring in nontraditional majors. Grant programs also assist the ET's diverse population through projects serving former welfare recipients, immigrants and refugees, domestic violence victims, dislocated workers, and the "working poor" (Horton, 2001).

West Valley College's ET program welcomes people of all nationalities and backgrounds, and has services tailored to the unique needs of individual adult learners. The re-entry program acknowledges the growing number of adults actively changing their lives through the educational process. Whether students are seeking to enhance their knowledge, learn new job skills, or prepare for a professional career, the re-entry program's staff members try to ease the transition for re-entry students returning to college.

Among the numerous services offered to re-entry students through the ET program are: academic, career, and personal counseling; assistance with the financial aid process; book and transportation vouchers; child care; facilitated support groups and workshops; Back-to-School Welcome programs; specialized orientation and educational planning sessions; job search and employment preparation workshops; mentoring programs; free income tax services; and an annual volunteer fair.

There is also an open lounge with ever-lasting fresh coffee and often some pastries and cookies. The first Thursday of each month, ET provides breakfast (bagels, cream cheese, and orange juice) to its students so they can socialize with other students like themselves. In addition, a binder in the ET lounge contains evaluations of West Valley College instructors completed by ET students. Students are encouraged to browse through the binder to find the best-fit instructor for their intended courses. 


\section{Conclusions}

The returning college student population is a diverse and complex group. Re-entry students needs vary greatly in light of individuals differences. As a means of helping re-entry students adjust to the college environment, colleges and universities must provide services to adults that will help them join in the mainstream as quickly as possible. Re-entry students need to know that they are an important segment of the educational institution and have assistance in overcoming obstacles in the way of their education. Programs such as the Educational Transition/Adult Re-entry Program can help adult students adjust to the college environment and assist them throughout their education.

One of the greatest needs of returning students, from experiences reported through West Valley College, is financial assistance. In spite of competing priorities, many adult students shift cash they could be using for other important items to education. Even though this indicates a willingness to forego material comforts, this is also a major cause of family stress. Educational institutions and the federal, state, and local government need to take into consideration the special challenges that adult students go through in order to make funds available for their tuition and books, not to mention their families' expenses. These students need assistance in different ways than younger students who may be supported by their families.

\section{Reference}

Horton, S. (Summer 2001). Assessment \& planning for programs \& services. Saratoga, CA: West Valley College, Office of Educational Transition Adult Re-Entry. 